\title{
Hubungan antara Tipe Mutasi Gen Globin dan Manifestasi Klinis Penderita Talasemia
}

\section{Correlation between Mutation Type of Globin Gene and Clinical Manifestations of Thalassemia}

\author{
Moedrik Tamam ${ }^{1}$, Suharyo Hadisaputro ${ }^{2}$, Sutaryo ${ }^{3}$, Iswari Setianingsih ${ }^{4}$, Rini Astuti ${ }^{5}$, Agustinus Soemantri ${ }^{1}$ \\ ${ }^{1}$ Departemen Ilmu Kesehatan Anak Fakultas Kedokteran Universitas Diponegoro/Rumah Sakit Umum Pusat Dr. Kariadi \\ Semarang \\ ${ }^{2}$ Departemen IImu Penyakit Dalam Fakultas Kedokteran Universitas Diponegoro/Rumah Sakit Umum Pusat Dr. Kariadi \\ Semarang \\ ${ }^{3}$ Departemen Ilmu Kesehatan Anak Fakultas Kedokteran Universitas Gajahmada Yogyakarta/Rumah Sakit Umum \\ Pusat Dr. Sardjito Yogyakarta \\ ${ }^{4}$ Lembaga Biologi Molekuler Eijkman, Jakarta \\ ${ }^{5}$ Unit Transfusi Darah Palang Merah Indonesia Kota Semarang
}

\begin{abstract}
ABSTRAK
Thalassemia $B$ di populasi umum mempunyai manifestasi klinis yang sangat bervariasi mulai dari thalassemia ringan sampai berat. Penentuan jenis mutasi adalah penting karena pengetahuan tentang tipe mutasi yang mendasari thalassemia- $\boldsymbol{B}$ diperlukan dalam pengelolaan pasien. Penelitian ini bertujuan untuk menilai hubungan antara tipe mutasi dengan manifestasi klinis penderita thalassemia. Penelitian ini merupakan penelitian observasional kohort prospective dilaksanakan di Unit Transfusi Darah (UTD PMI Kota Semarang mulai bulan Januari 2006-Desember 2009. Sampel menggunakan 38 pasien thalassemia yang dipilih secara purposive sampling dari penderita thalassemia 6 yang menerima transfusi. Variabel penelitian adalah jenis mutasi gen globin, manifestasi klinis, status gizi, dan kadar $\mathrm{Hb}$ sebelum dan sesudah transfusi. Pengukuran kadar Hb dilakukan sebelum transfusi ke-1, setelah transfusi ke-1 dan sebelum transfusi ke2. Analisis statistik menggunakan uji ${ }^{2}$ dan uji Fisher-exact. Rerata umur subyek penelitian adalah $10,1 \pm 3,26$ tahun, lakilaki sebesar 16 orang $(42,1 \%)$ dan perempuan 22 orang (57,9\%). Jenis mutasi adalah HbE/ivsnt1-nt5 (55,3\%), ivs1-nt5 dan HbE CD35 (masing-masing 13,2\%), HbE/ivs1-nt1 (7,9\%), dan ivs5-nt1/ivs1, ivs1-nt1/ivs1-nt1, HbE/CD41-42 dan exon 1-2 normal (masing-masing 2,6\%). Manifestasi klinis derajat sedang 65,8\% dan berat 34,2\%. Hasil uji statistik menunjukkan hubungan tidak bermakna antara jenis mutasi dengan manifestasi klinis thalassemia $(p=0,5)$. Jenis tipe mutasi gen globin tidak berhubungan dengan derajat manifestasi klinis thalassemia.
\end{abstract}

Kata kunci : Manifestasi klinis, talasemia , tipe mutasi

\begin{abstract}
Thalassemia in general population has wide clinical manifestatition variation of from mild or thalassemia minor until severe or thalassemia mayor. Determination of mutation type is important since understanding of type is necessary for patient management. The aim of this research is to investigate the correlation between mutation type and clinical manifestation of thalassemia patients. Observational cohort study has been conducted in Blood Transfusion Unit of Semarang City on January 2006-December 2009. Research subjects were 38 patients thalassemia. Study variables were mutation type and clinical manifestation of thalassemia including nutrition status, and $\mathrm{Hb}$ level. Measurements of $\mathrm{Hb}$ were conducted before transfusion I, after transfusion I and before transfusion II. Statistical analysis using ${ }^{2}$ and Fisherexact test. Average of age was $10.1 \pm 3.26$ year, sex was 16 boys (42.1\%) and 22 girls (57.9\%). Mutation type were HbE/ivsnt1-nt5 (55,3\%), ivs1-nt5 dan HbE CD35 (each 13,2\%), HbE/ivs1-nt1 (7,9\%), dan ivs5-nt1/ivs1, ivs1-nt1/ivs1-nt1, $\mathrm{HbE/CD41-42}$ and exon 1-2 normal (each 2,6\%). Clinical manifestations were moderate (65.8\%) and severe (34.2\%). Before transfusion II, about $78.1 \%$ patients have $\mathrm{Hb} \quad 8 \mathrm{~g} / \mathrm{dL}$ and $21.9 \%>8 / \mathrm{dL}$. Mutation type was not correlated to clinical thalassemia manifestation ( $p=0.5)$.
\end{abstract}

Keywords : Clinical manifestations, mutation type, thalassemia

Jurnal Kedokteran Brawijaya, Vol. 26, Februari 2010; Korespondensi: Moedrik Tamam. Rumah Sakit Umum Pusat Dr. Kariadi Semarang, Jl.Dr.Soetomo 16Semarang Tel. (024)8414296Email:moedriktamam@yahoo.com 


\section{PENDAHULUAN}

Kelainan genetik merupakan salah satu faktor yang berpengaruh terhadap kualitas sumber daya manusia (SDM). Salah satu kelainan genetik yang cukup banyak dijumpai pada anak adalah thalassemia. Thalassemia adalah kelainan genetik yang menyebabkan sintesis hemoglobin tidak ada atau kurang oleh karena gangguan sintesis rantai globin yang merupakan komponen utama hemoglobin. Adanya gangguan pembentukan rantai globin ini menyebabkan terjadinya rantai globin abnormal yang akan mengalami presipitasi dalam eritrosit. Hemoglobin dengan rantai globin abnormal tidak mampu mendistribusikan oksigen ke jaringan sehingga menimbulkan berbagai gangguan fungsi tubuh. Selain hal tersebut adanya presipitasi rantai globin abnormal tersebut juga berpengaruh terhadap manifestasi klinis thalassemia (1).

Manifestasi klinis thalassemia- $\boldsymbol{B}$ sangat beragam sesuai jenis mutasi gen globin- $\beta$ antara lain $\mathrm{HbE}$ yang frekuensinya banyak terdapat pada populasi di Asia Tenggara $(2,3)$. Sampai saat ini ditemukan 20 tipe mutasi gen globin- yang mendasari thalassemia-dan 8 tipe varian hemoglobin. Mutasi yang ringan seperti $\mathrm{HbE}$ dan $\mathrm{Hb}$ Malay merupakan tipe terbanyak dari mutasi thalassemia di populasi, sedangkan mutasi berat (IVS-1nt5) adalah yang paling banyak ditemukan pada penderita thalassemia . Frekuensi gen pembawa thalassemia di Indonesia adalah sekitar 3-8\%, sedangkan di beberapa negara mencapai $10 \%$. Artinya bahwa 3-8 dari 100 penduduk merupakan pembawa gen thalassemia. Jika diperkirakan persentase pembawa gen thalassemia di Indonesia ada 5\%, sedangkan angka kelahiran rata-rata $23 \%$ dan jumlah populasi penduduk sebanyak 240 juta, diperkirakan akan lahir 3000 bayi pembawa gen thalassemia setiap tahunnya (4). Semarang dengan jumlah penduduk mencapai 1.592 .632 pada tahun 2010 dengan angka rata-rata kelahiran $37 \%$ (5), diperkirakan akan lahir 29 bayi pembawa gen thalassemia setiap tahunnya.

Thalassemia $B$ di populasi umum termasuk mempunyai manifestasi klinis yang sangat bervariasi. Keadaan ini menimbulkan manifestasi klinik yang bervariasi dari thalassemia intemedia hingga thalassemia mayor $(6,7)$. Penentuan jenis mutasi menjadi penting karena pengetahuan tentang tipe mutasi yang mendasari thalassemia-b sangat diperlukan untuk mengetahui adanya hubungan dengan variasi klinis dan jumlah transfusi yang dibutuhkan. Informasi mengenai manifestasi klinis thalassemia- $B$ penting diketahui untuk penanganan klinik kasus-kasus thalassemia-b (8). Analisis mengenai jenis mutasi yang mendasari kelainan ini serta hubungannya dengan manifestasi klinis thalassemia $b$ belum banyak dilaporkan. Penelitian-penelitian sebelumnya juga menunjukkan adanya perbedaan hasil, disatu pihak jenis mutasi dijumpai sebagai faktor yang dapat digunakan untuk memprediksi derajat berat manifestasi klinis thalassemia, namun dilain pihak jenis mutasi tampak bukan faktor yang menentukan derajat berat manifestasi klinis thalassemia. Penelitian dilakukan untuk menjelaskan jenis mutasi yang mendasari manifestasi klinis penderita thalassemia $b$ dengan menggunakan data penderita thalassemia di Semarang.

\section{METODE}

Penelitian ini merupakan penelitian observasional longitudinal prospektif yang dilakukan di Unit Transfusi Darah (UTD) Palang Merah Indonesia (PMI) Kota Semarang pada periode Januari 2006 sampai dengan Desember 2009. Subyek penelitian adalah penderita thalassemia yang memperoleh transfusi secara reguler di UTD PMI Kota Semarang. Kriteria subyek penelitian adalah umur 6-14 tahun, tidak mendapatkan terapi hidroksiurea, kadar hemoglobin paska transfusi $10 \mathrm{gr} / \mathrm{dL}$. Pasien yang mengalami perdarahan, menderita sakit berat dan harus dirawat di rumah sakit, menderita defisiensi G6PD (diperiksa dengan tes reduksi Methylene Blue) atau yang menolak untuk ikut serta dalam peneltian tidak diikutsertakan dalam penelitian. Berdasarkan kriteria tersebut diperoleh 38 subyek penelitian, lebih dari jumlah sampel minimal yang dipersyaratkan dengan untuk uji hubungan sebanyak 29 subjek

\section{Manifestasi Klinis Thalassemia}

Manifestasi klinis thalassemia- ditentukan berdasarkan Sistem Penilaian Klinis Thailand (9), terdiri atas kriteria sebagai berikut: Rerata kadar $\mathrm{Hb}$ pra transfusi, usia pertama kali mendapat transfusi, frekuensi transfusi pertahun, kebutuhan transfusi darah setahun, ukuran limpa, usia pertama kali diagnosis ditegakkan, pertumbuhan dan perkembangan. Rentang skor: $0 \mathrm{~s} / \mathrm{d} 10$. kategori: Ringan ; 0-3, sedang ; 4-7, berat ; 7,5-10. Sistem penilaian klinis Thailand ini digunakan menimbang sistem penilaian tersebut telah digunakan secara luas dan mampu menilai interaksi antara genotip dan fenotip thalassemia. Selain itu ras Thailand dan Indonesia termasuk ras Asia Tenggara sehingga memiliki kesamaan yang lebih besar.

\section{Kadar Hemoglobin $(\mathrm{Hb})$}

Kadar $\mathrm{Hb}$ diperiksa menggunakan metoda SLS (Sodium Lauryl Sulfate) dari automated hematology analyzer. Kadar hemoglobin diperiksa 3 kali yaitu sebelum transfusi pertama, setelah transfusi pertama dan sebelum transfusi kedua. Hal ini dilakukan untuk menilai perubahan $\mathrm{Hb}$ sebelum dan pasca tranfusi.

\section{Status Gizi}

Status gizi ditentukan saat kunjungan pertama dengan mengukur Lingkar Lengan Atas (LiLA). Pengukuran LiLA menggunakan pita ukur (medline) pada pertengahan lengan atas antara processus acromion os clavicula dengan puncak olecranon os ulnae, satuan dalam milimeter. Triceps skin fold diukur dengan menggunakan Harpenden caliper pada pertengahan lengan atas antara processus acromion os clavicula dengan olecranon os ulnae. LiLA dinyatakan dalam persentile. Kategori LiLA persentil < 5\% : gizi buruk, persentil 5-15\%: gizi kurang, persentil 15-85\%: gizi baik, persentil $85-95 \%$ : overweight, persentil 95-100\%: obesitas.

\section{Analisis DNA}

Pemeriksaan DNA untuk menentukan jenis mutasi thalassemia $B$ dilakukan di Lembaga Biologi Molekuler Eijkman, Jakarta. Isolasi DNA dilakukan dengan metode Puregene yang dimodifikasi. Isolasi dilakukan dari sel darah putih menggunakan quick lysis atau Progenome. Pengukuran konsentrasi DNA menggunakan metode spektrofotometri. Pemeriksaan jenis mutasi thalassemia 
dilakukan dengan metode polymerase chain reactionrestriction fragment length polymorphism (PCR-RFLP) dan Amplification Refractory Mutation System-polymerase chain reaction (ARMS PCR). Metode PCR-RFLP digunakan untuk mencari mutasi thalassemia yang umum. Di Indonesia jenis yang sering ditemukan di Indonesia adalah IVS1-nt5 $(\mathrm{G}>\mathrm{C})$, IVS1-nt1 $(\mathrm{G}>\mathrm{T})$, kodon 15/Cd 15 $\left({ }^{T G} G^{\text {Triptofan }}>T \underline{A} G^{\text {stop }}\right)$, kodon $26 / H b E\left(\underline{G} A G^{\text {Glutamat }}>\underline{A} A G^{\text {Lysin }}\right)$ dan $\mathrm{Hb}$ Malay/kodon 19 (A $\underline{A} C^{\text {Aspargin }}>A \underline{G} C^{\text {Serin }}$ ). Metode ARMS PCR digunakan untuk mendeteksi adanya delesi besar gen globin.

Pemeriksaan dimulai dengan menentukan adanya mutasi umum. Pertama kali dicari adanya mutasi IVS1-nt5. Diagnosis mutasi IVS1-nt5 (G>C) ditegakkan apabila hasil analisis DNA menunjukkan mutasi IVS1-nt5 (G>C) homozigot. Apabila hasil normal atau heterozigot pemeriksaan dilanjutkan untuk menentukan mutasi IVS1nt2 $(T>C)$. Diagnosis mutasi IVS1-nt2 $(T>C)$ ditegakkan apabila hasil analisis DNA menunjukkan mutasi IVS1-nt2 $(\mathrm{T}>\mathrm{C})$ homozigot. Apabila hasil normal atau heterozigot pemeriksaan dilanjutkan untuk menentukan mutasi IVS1nt1 (G>T). Diagnosis mutasi IVS1-nt1 (G>T) ditegakkan apabila hasil analisis DNA menunjukkan mutasi IVS1-nt1 (G>T) homozigot. Apabila hasil normal atau heterozigot pemeriksaan dilanjutkan untuk menentukan mutasi Cd19 (AAC>AGC). Diagnosis mutasi Cd19 (AAC>AGC) ditegakkan apabila hasil analisis DNA menunjukkan mutasi Cd19 (AAC>AGC) homozigot. Apabila hasil normal atau heterozigot pemeriksaan dilanjutkan untuk menentukan mutasi IVS2-nt654 (C>T). Diagnosis mutasi IVS2-nt654 (C>T) ditegakkan apabila hasil analisis DNA menunjukkan mutasi IVS2-nt654 9C>t) homozigot. Apabila hasil normal atau heterozigot pemeriksaan dilanjutkan untuk menentukan mutasi Cd41-42 (delesi TTCT). Diagnosis mutasi Cd41-42 (delesi TTCT) (delesi TTCT) ditegakkan apabila hasil analisis DNA menunjukkan mutasi Cd41-42 (delesi TTCT) homozigot. Apabila tidak ditemukan mutasi diatas maka subyek dinyatakan sebagai belum ditemukan mutasi dan memerlukan pemeriksaan sequencing DNA lebih lanjut.

\section{Analisis Data}

Sebelum dilakukan analisis data normalitas data diuji dengan uji Saphiro Wilk. Perbedaan kadar $\mathrm{Hb}$ sebelum transfusi pertama, setelah transfusi pertama dan sebelum transfusi kedua dianalisis dengan uji Friedman yang dilanjutkan dengan uji Wilcoxon. Hubungan antara jenis mutasi dengan kategori kadar $\mathrm{Hb}$ dan manifestasi klinis dianalisis dengan uji 2. Nilai p dianggap bermakna apabila $\mathrm{p}<0,05$. Penelitian ini telah memperoleh Ethical clearance dari Komisi Etik Penelitian Kesehatan FK UNDIP/RSUP Dr. Kariadi Semarang (Ethical Clearance No. 22/EC/FK/RSDK/2005). Kesediaan pasien untuk ikut serta dalam penelitian diberikan dalam bentuk informed consent tertulis. Pasien yang menolak untuk berpartisipasi tetap mendapat pengelolaan sesuai dengan protap pengelolaan thalassemia di UTD PMI Kota Semarang dan RSUP Dr. Kariadi. Seluruh biaya ditanggung oleh peneliti dan subyek telah diberikan imbalan sesuai kemampuan peneliti.

\section{HASIL}

Pada periode penelitian di UTD PMI Kota Semarang dijumpai 80 penderita thalassemia- yang mendapatkan transfusi darah, namun pada penelitian ini hanya 38 pasien thalassemia- $b$ yang memenuhi kriteria penelitian. Karakteristik subyek penelitian menunjukkan rerata umur subyek penelitian adalah 10,1 tahun dengan usia termuda adalah 4 tahun dan tertua adalah 14 tahun. Jenis kelamin subyek penelitian sebagian besar adalah perempuan (57,9\%). Berdasarkan kategori LiLA sebagian besar termasuk gizi baik (42,1\%).

Rerata umur pertama kali transfusi adalah 3,7 $\pm 3,01$ tahun dengan rerata frekuensi transfusi adalah 6,67 \pm 5,41 $\mathrm{X} /$ tahun. Rerata jumlah darah transfusi dalam setahun adalah 4633,3 $\pm 2353,12$ cc. Riwayat splenektomi dijumpai pada 7 kasus $(18,4 \%)$ dan 31 kasus $(81,6 \%)$ belum mendapatkan splenektomi.

Rerata kadar $\mathrm{Hb}$ sebelum transfusi pertama adalah $\quad 10$ $\mathrm{g} / \mathrm{dL}$ yaitu $7,3 \pm 1,35 \mathrm{~g} / \mathrm{dL}$ dan setelah transfusi pertama meningkat menjadi $>10 \mathrm{mg} / \mathrm{dL}$ yaitu $12,6 \pm 0,43 \mathrm{~g} / \mathrm{dL}$. Berdasarkan rentang kadar $\mathrm{Hb}$ setelah transfusi pertama tidak dijumpai subyek dengan kadar $\mathrm{Hb} 10 \mathrm{~g} / \mathrm{dL}$. Selanjutnya rerata kadar $\mathrm{Hb}$ sebelum transfusi ke-2 menurun kembali $10 \mathrm{~g} / \mathrm{dL}$ yaitu 8,5 $\pm 1,17 \mathrm{~g} / \mathrm{dL}$, namun berdasarkan rentang nilai tampak adanya variasi yang cukup besar dimana kadar $\mathrm{Hb}$ terendah adalah 4,7 g/dL dan tertinggi adalah $13,1 \mathrm{~g} / \mathrm{dL}$. Hasil uji statistik menunjukkan adanya perbedaan yang bermakna perubahan kadar $\mathrm{Hb}$ sebelum transfusi pertama, setelah transfusi pertama dan sebelum transfusi kedua $(p<0,001)$. Hasil uji statistik juga menunjukkan perbedaan antara kadar $\mathrm{Hb}$ sebelum transfusi pertama dan setelah transfusi pertama adalah bermakna $(p<0,001)$, perbedaan antara kadar $\mathrm{Hb}$ setelah transfusi pertama dengan sebelum transfusi kedua adalah bermakna $(p<0,001)$ dan perbedaan antara kadar $\mathrm{Hb}$ sebelum transfusi pertama dengan sebelum transfusi kedua juga bermakna $(p<0,001)$. Perubahan kadar Hb juga ditampilkan pada Gambar 1.

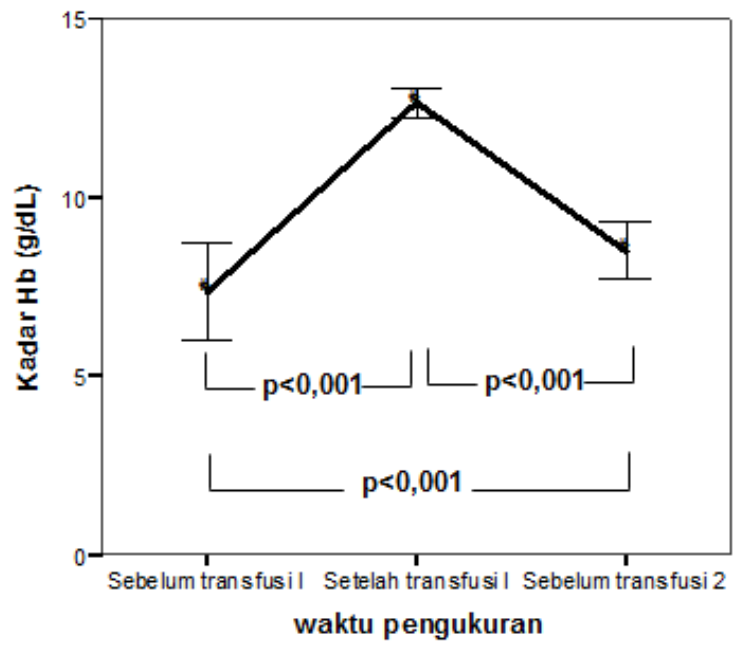

Gambar 1. Perubahan kadar Hb sebelum transfusi pertama, setelah transfusi pertama dan sebelum transfusi kedua ( $n=38)$. Error bar menunjukkan simpang baku.

Berdasarkan kategori manifestasi klinis Thailand, derajat manifestasi klinis subyek penelitian sebagian besar adalah derajat sedang yaitu 25 subyek $(65,8 \%)$, sedangkan berat 
sebanyak 13 subyek (34,2\%) dan tidak dijumpai subyek dengan derajat thalassemia ringan.

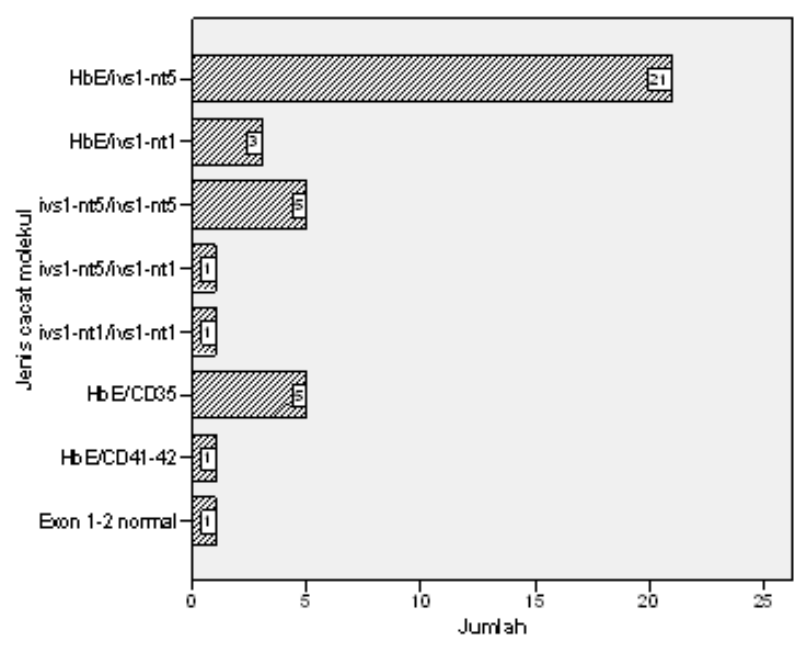

Gambar 2. Jenis cacat molekul gen globin pada subyek penelitian $(n=38)$. Nilai pada bar menunjukkan frekuensi.

Pada gambar 2 tampak jenis mutasi yang terbanyak dijumpai adalah $\mathrm{HbE}$ /ivsnt1-nt5 sebanyak 21 kasus (55,3\%), selanjutnya adalah ivs1-nt5 dan HbE CD35 masing-masing 5 kasus (13,2\%), HbE/ivs1-nt1 sebanyak 3 kasus (7,9\%), dan paling sedikit adalah ivs5-nt1/ivs1, ivs1nt1/ivs1-nt1, HbE/CD41-42 dan exon 1-2 normal masing 1 kasus (2,6\%).

Tabel 1. Hubungan antara jenis cacat molekul dengan derajat manifestasi klinis Thailand $(n=38)$.

\begin{tabular}{|c|c|c|c|}
\hline \multirow{2}{*}{ Jenis cacat molekul } & \multicolumn{2}{|c|}{ Derajat manifestasi klinis } & \multirow{2}{*}{ Total } \\
\hline & Sedang & Berat & \\
\hline $\mathrm{HbE} / \mathrm{ivs} 1-n+5$ & $13(61,9 \%)$ & $8(38,1 \%)$ & $21(100 \%)$ \\
\hline $\mathrm{HbE} / \mathrm{ivs} 1-\mathrm{nt} 1$ & $2(66,7 \%)$ & $1(33,3 \%)$ & $3(100 \%)$ \\
\hline ivs1-nt5/ivs1-nt5 & $4(80,0 \%)$ & $1(20,0 \%)$ & $5(100 \%)$ \\
\hline ivs1-nt5/ivs1-nt1 & $0(0,0 \%)$ & $1(100 \%)$ & $1(100 \%)$ \\
\hline ivs1-nt1/ivs1-nt1 & $0(0,0 \%)$ & $1(100 \%)$ & $1(100 \%)$ \\
\hline $\mathrm{HbE} / \mathrm{CD} 35$ & $4(80,0 \%)$ & $1(20,0 \%)$ & $5(100 \%)$ \\
\hline $\mathrm{HbE} / \mathrm{CD} 41-42$ & $1(100 \%)$ & $0(0,0 \%)$ & $1(100 \%)$ \\
\hline Exon 1-2 normal & $1(100 \%)$ & $0(0,0 \%)$ & $1(100 \%)$ \\
\hline Total & $25(65,8 \%)$ & $13(34,2 \%)$ & $38(100 \%)$ \\
\hline
\end{tabular}

jji $\chi^{2} ; p=0,5$

Persentase dihitung berdasarkan lajur

Pada tabel 1 tampak dari 21 subyek dengan jenis mutasi $\mathrm{HbE} /$ ivs1-nt5 sebagian besar $(61,8 \%)$ masih termasuk derajat sedang, hal yang sama juga tampak pada subyek dengan HbE/ivs1-nt1, ivs1-nt5/ivs1-nt5 dan HbE CD35. Pada subyek dengan jenis mutasi ivs1-nt5/ivs1-nt, ivs1nt1/ivs1-nt1 seluruhnya termasuk derajat berat, sedangkan subyek dengan $\mathrm{HbE} / \mathrm{CD} 41-42$ dan exon 1-2 normal seluruhnya termasuk derajat sedang. Hasil uji statistik menunjukkan hubungan antara jenis mutasi dengan manifestasi klinis thalassemia adalah tidak bermakna $(p=0,5)$.

\section{PEMBAHASAN}

Hasil penelitian ini menunjukkan jenis cacat molekul gen globin yang terbanyak dijumpai adalah HbE/ivs1-nt5. Thalassemia / $\mathrm{Hb} \mathrm{E}$ merupakan jenis thalassemia yang banyak ditemukan di Asia Tenggara. Frekuensi karier diperkirakan sebesar $50 \%$. Hb E baik dalam bentuk heterozigot maupun homozigot secara klinis adalah asimptomatis. Bila ditemukan bersama thalassemia, bentuk double heterozygot akan menghasilkan thalassemia / $\mathrm{HbE}$ yang secara klinis sama beratnya dengan thalassemia mayor atau intermedia dan membutuhkan transfusi reguler (10).

Prevalensi $\mathrm{HbE} / \mathrm{ivs1}$-nt5 pada penelitian ini lebih tinggi dengan hasil penelitian sebelumnya di Indonesia pada tahun 2006 yang melaporkan prevalensi ivs1-nt5 adalah sekiyar 35,3\%. Namun pada tahun 2009 peneliti yang sama melaporkan prevalensi $\mathrm{HbE}$ /ivs1-nt5 adalah berkisar $68,7 \%$ (11). Hasil penelitian ini serupa dengan yang dijumpai di Cina, mutasi ivs1-nt5 $(\mathrm{G}>\mathrm{C})$ merupakan jenis cacat molekul yang terbanyak dijumpai dengan prevalensi $48,3 \%$ (12). Hal yang sama juga dijumpai di Malaysia dengan prevalensi sebesar $48,3 \%$ (12). Berbeda dengan Indonesia dan Malaysia jenis mutasi ivs1-nt5 di Thailand hanya sekitar 5,2\% (13). Setelah HbE/ivs1-nt5, jenis mutasi yang berikutnya terbanyak dijumpai adalah $\mathrm{HbE} / \mathrm{CD} 35$ dan ivs1-nt5 (G>C)/ivs1-nt5 (G>C).

Mutasi IVS-1 nt5 (G>C) menyebabkan gangguan proses splicing pada mRNA. Splicing abnormal terjadi pada 3 lokasi (criptic sites) yang berbeda sehingga akan dihasilkan 3 jenis mRNA yang berbeda. Dua splicing abnormal terjadi pada ekson-1, hal ini menyebabkan terjadinya pemendekan rantai globin-. Satu splicing berikutnya terjadi pada intron, hal ini akan menghasilkan pemanjangan rantai globin-. Protein abnormal yang mengalami pemendekan umumnya mudah didegradasi dalam bentuk mRNA dalam inti sel atau menjadi polipeptida pada sitoplasma. Protein abnormal yang memanjang akan menghasilkan polipeptida yang panjang dan tetap akan mengalami proses translasi sehingga dihasilkan polipetida yang abnormal. Hal ini akan menimbulkan gangguan fungsi eritrosit (14). Pasien thalassemia-6/ $\mathrm{HbE}$ dengan ivs1-nt5 (G>C) memiliki manifestasi klinik yang lebih berat, berupa kadar $\mathrm{Hb}$ yang rendah, umur muda pada saat transfusi pertama, kadar $\mathrm{HbF}$ dan $\mathrm{HbE}$ yang rendah dan total transfusi dalam setahun yang lebih tinggi. Hasil penelitian ini menunjukkan sebagian besar subyek penelitian dengan jenis mutasi $\mathrm{HbE}$ /ivs1-nt5 trernasuk kategori derajat sedang. Hal ini berbeda dengan penelitian sebelumnya yang menyebutkan sebagian besar subyek dengan thalassemia/HbE dengan ivs1-nt5 memiliki manifestasi klinis derajat berat (11). Jenis mutasi ivs1-nt5 $(\mathrm{G}>\mathrm{C})$ termasuk mutasi berat yang masih didapatkan sintesis $\mathrm{HbA} 2$ yang merupakan $\mathrm{Hb}$ normal pada dewasa. Hal ini terlihat pada gambaran hemogram yang menunjukkan kadar $\mathrm{HbA} 2$ yang cukup tinggi. Adanya $\mathrm{Hb}$ dewasa yang cukup tinggi ini diduga berpengaruh pada manifestasi klinis thalassemia yang diderita, namun demikian pada penelitian ini juga terlihat kadar $\mathrm{Hb}$ pra transfusi penderita thalassemia$\mathrm{HbE}$ /ivs1-nt5 ( $\mathrm{G}>\mathrm{C})$ adalah tergolong rendah, sehingga diduga ada faktor non genetik seperti stress oksidatif, timbunan besi tubuh, status inflamasi dan faktor konstitusi seperti status gizi turut berpengaruh terhadap manifestasi klinis thalassemia. 


\section{UCAPAN TERIMA KASIH}

Peneliti mengucapkan terima kasih kepada Prof.Dr.dr. AG. Soemantri, SpAK, dr. Iswari Setianingsih, SpA, Ph.D, staf

\section{DAFTAR KEPUSTAKAAN}

1. Origa R and Galanello R. Pathophysiology of Beta Thalassaemia. Pediatric Endocrinology Review. 2011; 8(2): 263-270

2. Fucharoen $S$ and Winichagoon P. Hemoglobinopathies in Southeast Asia. Hemoglobin. 1987; 11(1): 65-88.

3. Weatherall D, Akinyanju O, Fucharoen S, Olivieri N, and Musgrove P. Inherited Disorders of Hemoglobin. In: Jamison DT, et al (Ed). Disease Control Priorities in Developing Countries. 2nd edition. New York: Oxford University Press; 2006.

4. Syam NRM, et al. The Spectrum of -Thalassemia Mutation in Indonesia: Differences Between The Mutation Distribution in Population and Patient Studies. Indonesia-Italy Meeting: Future Trends in Molecular Medicine, Eijkman Institute for Molecular Biology \& Instituto Italiano. Cultura, December 12-13, 2003.

5. Anonim. Data Kependudukan Kodya Semarang. (Online). http://id.wikipedia.org/ Kodya_Semarang [diakses tanggal 15 Desember 2010].

6. Olivieri NF, Pakbaz Z, and Vichinsky E. HbE/BThalassemia: Basis of Marked Clinical Diversity. Hematology/Oncology Clinics of North America. 2010; 24(6): 1055-1070.

7. Cappelini N, Cohen A, Eleftheriou A, Piga A, and Porter J. Guidelines for The Clinical Management of Thalassemia. Thalassemia International Federation. April 2000
UTD PMI Kota Semarang staf Lembaga Biologi Molekuler Eijkman, Jakarta, serta seluruh pihak yang telah membantu terselesaikannya penelitian ini.

8. Sripichai $\mathrm{O}$, Makarasara W, Munkongdee T, et al. A Scoring System for The Classification of BetaThalassemia/Hb E Disease Severity. American Journal of Hematology. 2008; 83(6): 482-484.

9. Setianingsih I. Molecular Basis of Beta-Thalassemia. Symposium New Horizon in Thalassemia Control From Gene to The Community. Jakarta, June 11-12, 2002; p. 5-41.

10. Wahidiyat PAW. Faktor-faktor Genetik Pengubah Manifestasi Klinis Thalassemia-/HbE: Interaksi Antara Mutasi Thalassemia, Polimorfisme Xmnl- ${ }^{G}$, dan SNPS pada Klaster Gen Globin. [Disertasi]. Universitas Indonesia, Jakarta. 2009.

11. Sofro ASM. Tinjauan Biomolekular dan Genetik Thalassemia. Naskah lengkap Kongres Nasional Ilmu Kesehatan Anak (KONIKA) XI. Jakarta, 1999.

12. Ainoon $\mathrm{O}$ and Cheong SK. Thalassemia in Malaysia: A Strategy for Prevention. The Malaysian Journal of Pathology. 1994; 16(1): 23-7.

13. Laosombat V, Wongchanchailert M, Sattayasevana B, Wiriyasateinkul A, and Fucharoen S. Clinical and Hematological Features of Beta(+)-Thalassemia (IVS 1 nt 5, G-C Mutation) in Thai Patients. European Journal of Haematology. 2001; 67(2): 100-104.

14. Nienhuis AW and Wolfe L. Hematology of Infancy and Childhood. In: Nathan DG, Oski FA, (Eds). The Thalassemia 3rd edition. Philadelphia: WB Saunders; 1987; p. 672-699. 